\title{
PENERAPAN METODE PROBLEM SOLVING DALAM MENINGKATKAN KEMAMPUAN PEMECAHAN MASALAH PADA MATA KULIAH ALJABAR DAN TRIGONOMETRI
}

\author{
Imelda \\ Universitas Katolik Santo Thomas Sumatera Utara \\ imelda_teach@yahoo.com
}

\begin{abstract}
This study is a classroom action research. The purpose of this research is (1) to describe the application of problem solving method in improving mathematics problem solving students of mathematics education program of Catholic University of Santo Thomas North Sumatera and (2) to describe the improvement of mathematics problem solving ability of mathematics education student in Algebra and Trigonometry. The result of this research shows that the result of problem solving test of mathematics cycle I is students who do not have problem solving ability as much as 3 people (30\%), while students have math problem solving ability as much as 7 people (70\%) and percentage of observation sheet lecturer activity amounted to $70.90 \%$. Based on the result of math problem solving test in cycle 2, there were $1(10 \%)$ students who did not have the ability to solve mathematics problem, while the students who have problem solving ability 9 students (90\%) and lecturer activity percentage of $85.50 \%$ experienced an increase from cycle I of 6.5\%. Based on the results of this acquisition then the group (classical) can be said that students have the ability to solve problems in Algebra and Trigonometry courses and increase problem-solving abilities by $20 \%$.
\end{abstract}

Keywords: problem solving method and problem solving ability.

\begin{abstract}
Abstrak. Penelitian ini adalah penelitian tindakan kelas. Tujuan penelitian ini adalah (1) mendeskripsikan penerapan metode problem solving dalam meningkatkan kemamuan pemecahan masalah matematika mahasiswa program studi pendidikan matematik Universitas Katolik Santo Thomas Sumatera Utara, (2) mendeskripsikan peningkatan kemampuan pemecahan masalah matematika mahasiswa program studi pendidikan matematika pada mata kuliah Aljabar dan Trigonometri. Hasil penelitian ini menunjukkan bahwa hasil tes kemampuan pemecahan masalah matematika siklus I adalah mahasiswa yang belum memiliki kemampuan pemecahan masalah sebanyak 3 orang $(30 \%)$, sedangkan mahasiswa yang telah memiliki kemampuan pemecahan masalah matematika sebanyak 7 orang $(70 \%)$ dan persentase lembar observasi terhadap aktivitas dosen sebesar 70,90\%. Berdasarkan hasil tes kemampuan pemecahan masalah matematika pada siklus 2 diperoleh 1 orang $(10 \%)$ mahasiswa yang belum memiliki kemampuan pemecahan masalah matematika, sedangkan mahasiswa yang telah memiliki kemampuan pemecahan masalah 9 orang mahasiswa $(90 \%)$ dan persentase aktifitas dosen sebesar 85,50\% mengalami peningkatan dari siklus I sebesar 6,5\%. Berdasarkan hasil perolehan ini maka secara kelompok (klasikal) dapat dikatakan mahasiswa telah memiliki kemampuan pemecahan masalah pada mata kuliah Aljabar dan Trigonometri dan peningkatan kemampuan pemecahan masalah sebesar $20 \%$.
\end{abstract}

Kata Kunci: metode problem solving dan kemampuan pemecahan masalah.

\section{PENDAHULUAN}

Pendidikan merupakan salah satu kegiatan yang dapat mengubah pola pikir manusia. Pendidikan merupakan hal yang penting jika tidak ingin tertinggal dengan negara-negara lainnya di dunia. Pendidikan Tinggi merupakan salah satu jenjang pendidikan di Indonesia yang terus berlomba untuk menciptakan manusia-manusia yang kompeten dan menghasilkan tamatan yang mampu bersaing di tengah globalisasi saat ini. Oleh karena itu, pendidikan tinggi diharapkan selalu melakukan perbaikan 
dalam pengembangan kurikulum yang diterapkan dengan tujuan memperbaiki kualitas pembelajaran dan hasil atau tamatannya. Kurikulum yang dirancang untuk meningkatkan kompetensi mahasiswa untuk dapat bersaing secara global adalah yang berdasarkan Standar Nasional Pendidikan Tinggi (SNPT).

Universitas Katolik Santo Thomas Sumatera Utara (Unika Santo Thomas) sebagai salah satu perguruan tinggi yang berlomba dalam peningkatan kompetensi lulusannya. Salah satu yang saat ini sedang dilakukan adalah perbaikan dan pengembangan kurikulum yang digunakan di Unika Santo Thomas. Kurikulum yang baru yang sedang dikembangkan dan diterapkan adalah kurikulum yang mengacu SNPT. Oleh karena itu, Program studi Pendidikan Matematika Unika Santo Thomas sebagai salah satu program studi yang sedang berusaha terus memperbaiki pembelajaran di kelas dan kualitas dosennya juga menerapkan kurikulum yang mengacu pada SNPT.

Aljabar dan Trigonometri merupakan salah satu mata kuliah yang diajarkan di program studi pendidikan matematika. Dalam mata kuliah aljabar dan trigonometri mahasiswa diharapkan dapat memiliki keahlian dan keterampilan dalam menyelesaikam masalah matematika dalam bidang aljabar dan trigonometri. Pada kurikulum sebelumnya, tidak ada mata kuliah ini sehingga materi aljabar di sampaikan sebagai pendahuluan dalam matakuliah aljabar linier elementer dan materi trigonometri dimasukkan dalam mata kuliah kalkulus. Akan tetapi pada kurikulum baru, materi aljabar dan trigonometri akan dibahas secara mendalam sehingga untuk mata kuliah lanjutannya seperti aljabar linier elementer tidak perlu membahas lagi materi aljabarnya sebagai pendahuluan.

Pembelajaran mata kuliah Aljabar dan Trigonometri bukan hanya sekedar membagikan pengetahuan dan informasi, akan tetapi lebih dari pada itu. Sebaiknya pembelajaran yang dilakukan harus memperhatikan kemampuan berfikir anak yaitu penalaran, berfikir logis, kemampuan komunikasi, berfikir kritis, dan kemampuan pemecahan masalah. Kemampuan pemecahan masalah amat penting dalam matematika, bukan hanya untuk mereka yang akan mendalami tau mempelajari matematik, melainkan juga bagi mereka yang akan menerapkannya dalam ilmu lain dan dalam kehidupn sehari-hari (Ruseffendi, 2006). Dalam memecahkan masalah matematika terdapat beberapa langkah yang harus diketahui. Menurut Polya (1973) pemecahan masalah matematika terdiri atas empat langkah yang harus dilakukan, yaitu; memahami masalah (understanding the problem), menyusun rencana (devising a plan), melaksanakan rencana (carrying out the plan) dan memeriksa kembali (looking back).

Kemampuan pemecahan masalah merupakan salah satu kemampuan yang sangat penting untuk ditingkatkan. Untuk mengembangkan kemampuan pemecahan masalah seseorang, tidak cukup hanya latihan berfikir secara matematis saja, melainkan perlu dibarengi pengembangan rasa percaya diri melalui proses pemecahan masalah sehingga memiliki kesiapan memadai menghadapi berbagai tantangan dalam kehidupan nyata. Dalam mengembangkan kemampuan siswa dalam pemecahanmasalah, hal yang juga perlu ditingkatkan adalah kemampuan menyangkut berbagai teknik dan strategi pemecahan-masalah. Pengetahuan, keterampilan, dan pemahaman, merupakan elemen-elemen penting dalam belajar matematika. Dalam pemecahan masalah, siswa dituntut memiliki kemampuan untuk mensintesis elemen-elemen tersebut sehingga akhirnya dapat menyelesaikan masalah yang dihadapi dengan baik.

Mahasiswa program studi pendidikan matematika semester satu merupakan 
mahasiswa yang pertama sekali mengikuti matakuliah Aljabar dan Trigonometri. Mahasiswa baru ini belum terbiasa dengan sistem perkuliahan yang sangat berbeda dengan sistem di sekolah. Berdasarkan wawancara dengan beberapa mahasiswa diperoleh informasi bahwa mereka sangat senang dengan dosen yang tepat datang dan memberi tugas, memeriksa tugas dan memberi nilai pada setiap tugas. Akan tetapi, mereka tidak senang dengan adanya dosen yang jarang memberi tugas dan jika memberi tugas, tugasnya tidak diperiksa. Hal ini menunjukkan bahwa mahasiswa masih terbiasa dengan pola pembelajaran di sekolah.

Dalam pembelajaran Aljabar dan Trigonometri, dosen selalu memberikan tugas untuk dikerjakan di kelas ataupun tugas di rumah. Mahasiswa senang, karena setiap tugas akan dinilai dan akan dimasukkan dalam daftar nilai tugas yang dibuat dosen. Soal-soal yang diberikan biasanya adalah soal cerita yang berkaitan dengan materi aljabar. Akan tetapi, ada beberapa hal yang menjadi perhatian dosen dalam hasil pengerjaan tugas yang diberikan. Bahwa dalam menyelesaiakan soal teks, mahasiswa masih belum mampu menyelesaikannya dengan baik dan benar. Hal ini dapat dilihat dari jawaban siswa yang tidak menuliskan yang diketahui dan yang ditanya, serta tidak menemukan rencana apa untuk menyelesaikan masalah serta tidak mengerti bagaimana caranya menyelesaiakan masalah yang diberikan. Hal ini menunjukkan bahwa kemampuan pemecahan masalah matematika bagi mahasiswa program studi pendidikan matematika semester satu harus mendapat perhatian.

Keadaan awal kemampuan pemecahan masalah matematika dapat dilihat dari hasil tes awal yang diberikan yang terdiri dari 4 soal pemecahan masalah yang disusun berdasarkan indikator pemecahan masalah matematika. Hasil yang diperoleh adalah bahwa hanya 1 orang dengan nilai 82 dan 2 orang dengan nilai 75, 4 orang dengan nilai 63, 2 orang dengan nilai 9 dan 1 orang dengan nilai 25. Berdasarkan nilai yang diperoleh dapat disimpulkan bahwa hanya $10 \%$ siswa yang memiliki kemampuan pemecahan masalah sedangkan $90 \%$ masih harus dilatih dan diperbaiki kemampuan pemecahan masalahnya. Ini berarti bahwa kemampuan pemecahan masalah matematika mahasiswa semester satu prodi pendidikan matematika masih rendah.

\section{METODE}

Penelitian ini merupakan Penelitian Tindakan Kelas (Classroom Action Research) dengan tujuan meningkatkan kemampuan pemecahan masalah matematika mahasiswa pada mata kuliah Aljabar dan Trigonometri. Penelitian dilaksanakan di program studi pendidikan Matematika Universitas Katolik Santo Thomas Sumatera Utara di Jalan Setia Budi No. 479-F Tanjung Sari-Medan semester ganjil tahun pembelajaran 2017/2018. Subjek penelitian ini adalah mahasiswa semester 1 Prodi Pendidikan Matematika FKIP Universitas Katolik Santo Thomas Sumatera Utara tahun pembelajaran 2017/2018 yang berjumlah 10 orang mahasiswa dengan komposisi 9 orang mahasiwa laki-laki dan 1 orang mahasiswa perempuan. Sedangkan objek dalam penelitian ini adalah peningkatan kemampuan pemecahan masalah pada matakuliah Aljabar dan Trigonometri mahasiswa prodi pendidikan matematika Unika Santo Thomas dengan penerapan metode problem solving.

Data yang diperoleh dalam penelitian ini adalah: data tentang kemampuan pemecahan masalah pada mata kuliah Aljabar dan Trigonometri yang diperoleh dari tes uraian atau soal cerita materi Aljabar dan Trigonometri. Keberhasilan penelitian ini jika minimal 80\% siswa telah memiliki skor kemampuan pemecahan masalah (SKM) dengan minimal kategori cukup baik, lembar observasi kegiatan guru minimal 80\%. 


\section{HASIL DAN PEMBAHASAN}

Berdasarkan hasil pengamatan peneliti dan diskusi dengan observer, mulai dari siklus I sampai siklus II (masing-masing 4 kali pertemuan) terdapat beberapa hal yang ditemukan saat pembelajaran berlangsung, yaitu:

\section{Penerapan Metode Problem Solving}

Sebelum siklus I dimulai, pada tanggal 16 Oktober 2017 mahasiswa diberikan tes pengetahuan materi prasyarat dengan tujuan: (1) untuk mengetahui sampai sejauh mana mahasiswa menguasai materi prasyarat, (2) untuk melihat kesiapan mahasiswa terhadap materi baru yang akan diberikan. Gambaran umum hasil tes pengetahuan materi prasyarat dengan rata-rata 45,1 dengan standar deviasi 7,93. Mengacu pada pengkategorian skor skala lima, dengan menggunakan kedua nilai ini disusun interval Skor Pengetahuan Materi Prasyarat (SPMP) dan pengkategorian skor. Hal ini menunjukkan bahwa mahasiswa yang telah memiliki penguasaan materi prasyarat dengan kategori minimal cukup baik sebanyak 7 orang (70\%) sedangkan mahasiswa yang belum memiliki penguasaan materi prasyarat yang baik sebanyak 3 orang (30\%). Dengan demikian, seiring dengan berjalannya siklus 1 maka mahasiswa yang belum memiliki penguasaan materi prasyarat harus dibimbing oleh dosen untuk meningkatkan pengetahuan materi prasyaratnya.

\section{SIKLUS I}

\section{Perencanaan}

Tahapan pertama yang dilakukan pada siklus ini adalah analisis kurikulum untuk menentukan standar kompetensi dan kompetensi dasar yang akan disampaikan kepada mahasiswa dengan menggunakan metode problem solving. Selanjutnya adalah penyusunan perangkat pembelajaran berupa: Rencana Pelaksanaan Pembelajaran (RPP). Rencana pembelajaran yang disusun untuk pertemuan pertama hingga ke empat pada siklus 1 difokuskan untuk meningkatkan kemampuan pemecahan masalah matematika mahasiswa Seluruh perangkat yang disusun didasarkan pada karakteristik dan langkah-langkah metode pembelajaran problem solving.

Setelah penyusunan perangkat pembelajaran, kemudian tahapan perencanaan selanjutnya adalah penyusunan instrumen penelitian. Instrumen yang disusun adalah tes kemampuan pemecahan masalah matematika mahasiswa pada mata kuliah Aljabar dan Trigonometri siklus 1 terdiri dari 5 soal. Tahapan kedua adalah penyusunan instrumen lembar observasi dosen untuk memperoleh persentase aktivitas dosen di dalam kelas. Lembar observasi aktivitas dosen yang berorientasi pada langkahlangkah metode problem solving.

\section{Pelaksanaan}

Pelaksanaan tindakan pada siklus 1 merupakan implementasi dari persiapan atau rancangan yang disusun pada tahap perencanaan. Penerapan pembelajaran dengan metode problem seolving. Tahapan pembelajaran dengan metode problem solving dilakukan dalam 4 langkah pembelajaran. Langkah-langkah pelaksanaan pembelajaran dengan metode problem solving yaitu: 1) Memahami masalahnya, 2) Menyusun rencana penyelesaian, 3) Melaksanakan rencana penyelesaian, dan 4) Memeriksa kembali penyelesaian yang telah dilakukan. Pada tahap awal mahasiswa diberikan masalah yang berkaitan dengan materi Aljabar. Masalah yang diberikan adalah soal pemecahan masalah dan mahasiswa harus mampu memahami masalah dengan menuliskan informasi apa yang diperoleh dari masalah yang ada. Misalnya 
menuliskan apa yang diketahui dan apa yang ditanya dari masalah yang ada. Tahap kedua, mahasiswa menyusun rencana penyelesaian masalah dengan memperhatikan informasi yang diperoleh dari langkah awal. Tahap ketiga, Mahasiswa menyelesaikan dan menemukan penyelesaian atas masalah dengan mengerjakan sesuai dengan rencana yang telah dibuat di langkah kedua. Tahap keempat, berdasarkan jawaban yang telah diperoleh di langkah ketiga maka mahasiswa memriksa kembali jawaban yang telah diperolehnya dan menentukan kesimpulan sebagai jawaban yang benar atas masalah yang telah diberikan.

Pertemuan pertama hingga pertemuan keempat merupakan usaha untuk meningkatkan kemampuan pemecahan masalah matematika. Hasil penelitian tindakan yang akan dianalisis secara deskriptif adalah persentasi lembar observasi aktivitas dosen dan data hasil tes kemampuan pemecahan masalah pada mata kuliah Aljabar dan Trigonometri. Persentase lembar observasi aktivitas dosen pada siklus I adalah $79 \%$. Gambaran umum hasil tes kemampuan pemecahan masalah matematika siklus I diperoleh nilai tertinggi 80 dan nilai terendah 57, rata-rata 65,10 dengan standar deviasi sebesar 7,93. Mengacu pada pengkategorian skor skala lima, dengan menggunakan kedua nilai ini disusun interval skor kemampuan pemecahan masalah matematika. Mahasiswa yang belum memiliki kemampuan pemecahan masalah sebanyak 3 orang (30\%), sedangkan mahasiswa yang telah memiliki kemampuan pemecahan masalah matematika sebanyak 7 orang (70\%). Berdasarkan hasil perolehan ini maka secara kelompok (klasikal) dapat dikatakan mahasiswa belum memiliki kemampuan pemacahan masalah matematika pada matakuliah aljabar dan Trigonometri.

\section{Observasi}

Pengamatan atau observasi adalah bagian dari proses pengumpulan data yang diperlukan dalam penelitian ini. Pengamatan dalam penelitian ini dilaksanakan ketika proses tindakan berlangsung yang dilakukan oleh observer. Observer dalam penelitian ini adalah salah satu dosen program studi pendidikan matematika Unika Santo Thomas. Observer bersama peneliti memiliki peran mengamati dan memotret semua peristiwa yang terjadi di kelas ketika tindakan dilakukan. Pengamatan diarahkan pada aspek yang menjadi perhatian penelitian, yaitu kegiatan belajar dan setting pembelajaran dengan metode problem solving. Hasil observasi berupa catatan peneliti sebagai bahan pertimbangan tindakan pada siklus II.

\section{Refleksi}

Kelemahan dari pembelajaran dengan metode problem solving yang telah dilakukan adalah: Pertama, pada tahap pertama mahasiswa mencari data yang diperlukan untuk memecahkan masalah. Terdapat beberapa siswa yang belum mampu mencari data yang membantu menyelesaikan masalah. Mahasiswa tidak mampu mendefenisikan apa yang diketaui dan yang ditanya sehingga tidak menemukan solusi. Kedua, pada tahap kedua mahasiswa tidak menuliskan rencana penyelesaian masalah. Mahsiswa langsung mengerjakan penyelesaian dan mencoba langsung mengerjakan tanpa ada rencana penyelesaian terlebih dahulu. Ketiga, pada tahap keempat mahasiswa masih tidak memriksa kembali jawaban yang telah ditemukan. Akan tetapi langsung membuat kesimpulan sebagai jawaban akhir terhadap masalah yang ada.

Dari berbagai kelemahan mahasiswa dan kelemahan dosen yang ditemui dalam pembelajaran siklus I ini, maka dosen perlu melakukan perbaikan terhadap tindakan 
pembelajaran agar kelemahan-kelemahan ini tidak terjadi atau terulang di siklus II. Rencana tindakan yang dilakukan pada siklus II untuk mengatasi kelemahankelemahan yang terjadi pada siklus I antara lain: Pertama, meminta mahasiswa untuk membaca dengan cermat dan lebih fokus dalam menentukan apa yang diketahui dan apa yang ditanya dan menuliskan semua informasi yang ada pada masalah sehingga mahasiswa benar-benar memahami masalah. Kedua, meminta siswa untuk mulai menuliskan rencana pemecahan masalah dalam menyelesaikan setiap masalah yang ditemukan. Ketiga, dosen mengingatkan mahasiswa untuk memeriksa kembali jawaban yang telah dibuat dan membuat kesimpulan atas masalah yang ada.

Berdasarkan indikator kinerja, secara klasikal mahasiswa masih belum memiliki kemampuan pemecahan masalah matematika siklus 1 dan aktivitas dosen dalam lembar observasi belum mencapai minimal $80 \%$ sehingga dilanjutkan dalam pembelajaran dengan metode problem solving pada siklus 2 dengan perbaikan tindakan pembelajaran sebagaimana yang telah diungkapkan.

\section{SIKLUS II}

\section{Perencanaan}

Tahapan pertama yang dilakukan pada siklus ini adalah melakukan analisis kurikulum untuk menentukan standar kompetensi dan kompetensi dasar yang akan disampaikan kepada mahasiswa dengan metode problem solving. Selanjutnya adalah penyusunan perangkat pembelajaran berupa: RPP dan lembar Aktivitas Mahasiswa. Seluruh perangkat yang disusun didasarkan pada karakteristik dan langkah-langkah pembelajaran dengan metode problem solving. Sama halnya pada siklus 1, rencana pembelajaran yang disusun untuk pertemuan kelima sampai pertemuan kedelapan juga difokuskan untuk meningkatkan kemampuan pemecahan masalah matematika. Setelah penyusunan perangkat, kemudian tahapan perencanaan selanjutnya adalah penyusunan instrumen penelitian. Instrumen pertama yang disusun adalah tes kemampuan pemecahan masalah matematika pada mata kuliah aljabar dan trigonometri. Tes kemampuan pemecahan masalah matematika sebanyak 5 soal essay. Lembar observasi aktifitas dosen disusun berdasarkan langkah-langkah pembelajaran dengan metode problem solving. Sebagai rencana perbaikan tindakan pada siklus II sebagai upaya mengatasi kelemahan-kelemahan yang terjadi pada siklus I yaitu dosen selalu mengingatkan mahasiswa untuk memahami masalah, menuliskan rencana penyelesaian masalah dan memeriksa kembali jawaban yang telah ditemukan pada langkah ketiga sehingga diperoleh jwaban yang benar.

\section{Pelaksanaan}

Pelaksanaan tindakan siklus 2 merupakan implementasi dari persiapan atau rancangan yang disusun sebelumnya. Berdasarkan hasil tes kemampuan pemecahan masalah matematika pada siklus 2 diperoleh rata-rata kemampuan pemecahan masalah matematika pada mata kuliah Aljabar dan Trigonometri pada siklus 2 adalah 78.50 dengan standar deviasi 9.5 dimana nilai tertinggi 95 dan nilai terendah 60. Mengacu pada pengkategorian skor skala lima, dengan menggunakan nilai standar deviasi dan mean disusun interval skor kemampuan pemecahan masalah matematika. Berdasarkan hasil analisis data pada siklus 2 diperoleh bahwa mahasiswa yang belum memiliki kemampuan pemecahan masalah matematika sebanyak 1 orang $(10 \%)$, sedangkan mahasiswa yang telah memiliki kemampuan pemecahan masalah 9 orang mahasiswa (90 \%). Berdasarkan hasil perolehan ini maka secara kelompok (klasikal) dapat 
dikatakan mahasiswa telah memiliki kemampuan pemecahan masalah pada mata kuliah Aljabar dan Trigonometri. Berdasarkan lembar observasi aktifitas dosen diperoleh persentase aktivitas dosen adalah 85,50\% mengalami peningkatan dari siklus 1 sebesar $6,5 \%$.

\section{Pengamatan}

Pengamatan atau observasi adalah bagian dari proses pengumpulan data yang diperlukan penelitian. Pengamatan dalam penelitian ini dilaksanakan ketika proses tindakan berlangsung yang dilakukan oleh pengamat (observer). Observer (pengamat) dalam penelitian ini adalah seorang dosen Pendidikan Matematika Unika Santo Thomas Sumatera Utara. Observer bersama peneliti memiliki peran mengamati dan memotret semua peristiwa yang terjadi di kelas ketika tindakan dilakukan. Pengamatan difokuskan ke aspek-aspek yang menjadi perhatian penelitian, yaitu kegiatan belajar dan catatan lapangan.

Berdasarkan hasil pengamatan peneliti dan observer diperoleh bahwa pada tahap pembelajaran dengan metode problem solving mahasiswa merasa senang dan tertarik untuk menyelesaikan masalah-masalah matematika yang diberikan. Mahasiswa lebih aktif dalam mengerjakan masalah yang diberikan.

\section{Refleksi}

Masalah yang diberikan kepada mahasiswa diselesaikan sesuai dengkan langkah-langkah pemecahan masalah. Mahasiswa dibimbing dan dituntun untuk melalui langkah memahami masalah, merencanakan penyelesaian masalah, melaksanakan penyelesaian masalah dan memeriksa kembali jawaban yang telah dibuat. Mahasiswa senang dan tertantang untuk menyelesaikan masalah yang diberikan pada siklus 2 .

\section{Pembahasan}

Peningkatan kemampuan pemecahan masalah matematika mahasiswa dilihat berdasarkan tes kemampuan pemecahan masalah matematika setiap siklus. Berdasarkan perolehan nilai pada siklus pertama dan siklus kedua, disimpulkan bahwa kemampuan pemecahan masalah matematika mahasiswa mengalami peningkatan. Interaksi dalam kegiatan pembelajaran matematika dengan metode problem solving berbasis masalah matematika. Soal pemecahan masalah diselesaikan dengan langkahlangkah metode problem solving yaitu memahami masalah, merencanakan penyelesaian masalah, menyelesaikan masalah dan memeriksa kembali.

Berdasarkan langkah-langkah pembelajaran dengan metode problem solving, pembelajaran lebih fokus pada masalah-masalah matematika dalam kehidupan seharihari yang berkaitan dengan materi Aljabar dan Trigonometri. Masalah yang diberikan kepada mahasiswa sesuai dengan perkembangan kognitif mahasiswa sehingga memungkinkan mahasiswa untuk menggunakan pengalaman mahasiswa sebelumnya. Masalah yang harus diselesaikan mahasiswa melatih mahasiswa dalam memecahkan masalah matematika yang kemudian diharapkan mampu memecahkan masalahmasalah dalam kehidupan sehari-hari.

Secara teoritis pembelajaran dengan metode problem solving memiliki beberapa keunggulan, dimana jika keunggulan-keunggulan tersebut mampu dimaksimalkan dalam pembelajaran di kelas maka akan mampu meningkatkan kemampuan 
pemecahan masalah matematika mahasiswa program studi Pendidikan Matematika Universitas Katolik Santo Thomas Sumatera Utara.

\section{Saran}

Temuan penelitian, hasil analisis data, perangkat pembelajaran, maupun instrumen yang dihasilkan dalam penelitian ini dapat dijadikan referensi dalam upaya peningkatan kemampuan pemecahan masalah matematika pada mata kuliah Aljabar dan Trigonometri.

Bagi dosen yang hendak menerapkan pembelajaran dengan metode problem solving hendaknya: (1) benar-benar memahami kajian teori tentang langkah-langkah pembelajaran matematika dengan metode problem solving. (2) Melibatkan semua mahasiswa agar berinteraksi secara positif, diawali dari masalah yang diberikan dosen.

\section{DAFTAR PUSTAKA}

Beck, Pam. 2005.Mathematics Assesment a practical Handbook for grades 6-8. USA: NCTM.

Hudoyo, H. 2003. Pengembangan Kurikulum dan Pembelajaran Matematika. Malang: UM Press.

Kusumah, Y. S. 2004. Model-Model Pembelajaran Matematika untuk Meningkatkan Kemampuan Kognitif dan Afektif Siswa Sekolah Menengah. Makalah Disampaikan pada tanggal 12 Oktober 2004 di FMIPA UNY.

Madya, S. 1994. Panduan Penelitian Tindakan. Yogyakarta: Lembaga PenelitianIKIP YOGYAKARTA

Ollerton, M. 2007. March. Teaching and Learning through Problem Solving. ProQuest Education Journals.

Polya, G. 1973. How to Solve it. New Jersey: Princeton University Press.

Reys, R. S., \& dkk. 1998. Helping Children Learn Mathematics. Needham Height: Allyn \& Bacon.

Ruseffendi, E.T. 2006. Pengantar Kepada Membantu Guru Mengembangkan Kompetensinya dalam Pengajaran Matematika. Bandung: Tarsito.

Shadiq, S. 2009. Sistem Pembinaan dan Karakteristik Soal Olimpiade Matematika. Yogyakarta: PPPPTK Matematika.

Sufatimah, H. 2010. Upaya Meningkatkan Kemampuan Pemecahan Masalah dalam Pembelajaran Matematika melalui Pelaksanaan Metode Penemuan Terbimbing pada Siswa Kelas XI IPA di MAN Godean, Skripsi. Yogyakarta: UNY.

Suherman, E. 2003. Strategi Pembelajaran Matematika Kontemporer. Bandung: JICA.

Sujono. 1988. Pengajaran Matematika untuk Sekolah Menengah. Jakarta: Proyek Pengembangan LPTK, Depdikbud

Sukirman, dkk. 2005. Matematika. Jakarta: Universitas Terbuka.

Sumarmo, U, Dedy, E dan Rahmat. 1994. Suatu Alternatif Pengajaran untuk Meningkatkan Pemecahan Masalah Matematika pada Guru dan Siswa SMA. Laporan Hasil Penelitian FPMIPA IKIP Bandung.

Trianto. 2015. Model Pembelajaran Terpadu. Jakarta: Bumi Aksara. 